\title{
Interleukin-6 (IL-6) Production by Astrocytes: Autocrine Regulation by IL- 6 and the Soluble IL-6 Receptor
}

\author{
Nicholas J. Van Wagoner, Jae-Wook Oh, Pavle Repovic, and Etty N. Benveniste \\ Department of Cell Biology, The University of Alabama at Birmingham, Birmingham, AL 35294-0005
}

In the CNS, astrocytes are a major inducible source of interleukin-6 (IL-6). Although IL-6 has beneficial effects in the CNS because of its neurotrophic properties, its overexpression is generally detrimental, adding to the pathophysiology associated with CNS disorders. Many factors have been shown to induce IL-6 expression by astrocytes, particularly the cytokines tumor necrosis factor- $\alpha$ (TNF- $\alpha$ ) and interleukin-1 $\beta$ (IL-1 $\beta$ ). However, the role of IL- 6 in its own regulation in astrocytes has not been determined. In this study, we examined the influence of IL-6 alone or in combination with TNF- $\alpha$ or IL-1 $\beta$ on IL-6 expression. IL-6 alone had no effect on IL-6 expression; however, the addition of the soluble IL-6 receptor (sIL-6R) induced IL- 6 transcripts. Addition of TNF- $\alpha$ or IL- $1 \beta$ plus IL-6/sIL-6R led to synergistic increases in IL-6 expression. This synergy also occurred in the absence of exogenously added IL-6, attributable to TNF- $\alpha$ - or IL- $1 \beta$-induced endogenous IL-6 protein production. IL- 6 upregulation seen in the presence of TNF- $\alpha$ or IL-1 $\beta$ plus IL-6/sIL-6R was transcriptional, based on nuclear run-on analysis. Experiments were extended to other IL-6 family members to determine their role in IL-6 regulation in astrocytes. Oncostatin M (OSM) induced IL-6 alone and synergized with TNF- $\alpha$ for enhanced expression. These results demonstrate that IL-6/sIL-6R and OSM play an important role in the regulation of IL-6 expression within the CNS, particularly in conjunction with the proinflammatory cytokines TNF- $\alpha$ and IL-1 $\beta$.

Key words: glial cells; cytokines; interleukin-6; central nervous system; receptors; astrocytes
Interleukin-6 (IL-6) is a regulator of inflammatory and immunological responses, and belongs to a family of neuropoietic factors including ciliary neurotrophic factor (CNTF), leukemia inhibitory factor (LIF), oncostatin M (OSM), IL-11, and others (for review, see Taga and Kishimoto, 1997; Heinrich et al., 1998). Characteristic of this family is the pluripotency and redundancy of biological responses elicited by its members, which stem from the use of a common signal transducing receptor, gp130 (for review, see Taga and Kishimoto, 1997). IL-6 acts on target cells through a receptor complex composed of an IL-6-binding subunit, the IL- 6 receptor- $\alpha$ (IL-6R $\alpha$ ), and the signal transducing receptor gp130. Initiation of IL-6 signaling occurs when IL-6 binds to the IL-6R $\alpha$, leading to an association with gp130. This event leads to activation of gp130-associated Janus kinases (JAKs), activation of various signaling pathways (JAK/STAT, MAPK), and subsequent gene activation (for review, see Taga and Kishimoto, 1997). The IL-6R $\alpha$ is found in both membranebound and soluble (sIL-6R $\alpha$ ) forms (Lust et al., 1992; Müllberg et al., 1993). The sIL-6R $\alpha$ can complex with IL-6, bind, and signal through gp130, thus serving as an agonist of IL-6-induced responses (for review, see Rose-John and Heinrich, 1994). The sIL-6R $\alpha$ can be generated by shedding of the membrane-bound receptor or by mRNA alternative splicing (Lust et al., 1992; Müllberg et al., 1993).

Received Nov. 18, 1998; revised April 2, 1999; accepted April 3, 1999.

This work was supported by National Institutes of Health Grants NS29719 and MH55795 (E.N.B.). N.J.V. was supported by a National Institutes of Health Predoctoral Fellowship (5-T32 GM08111), and J-W.O. is supported by a Postdoctoral Fellowship (FG1308-A-1) from the National Multiple Sclerosis Society. We thank Evelyn Rogers for secretarial assistance and Professor Stefan Rose-John (Universität Mainz) for the Hyper-IL-6.

Correspondence should be addressed to Dr. Etty N. Benveniste, Department of Cell Biology, The University of Alabama at Birmingham, 1918 University Boulevard, MCLM 350, Birmingham, AL 35294-0005.

Copyright () 1999 Society for Neuroscience 0270-6474/99/195236-09\$05.00/0
Under physiological conditions, IL-6 levels in the CNS remain low. However, in CNS injury and inflammation, IL-6 levels become elevated (for review, see Gruol and Nelson, 1997; Benveniste, 1998). Elevated levels of IL-6, as well as the proinflammatory cytokines IL- $1 \beta$ and tumor necrosis factor (TNF)- $\alpha$, are detected in the CSF of patients with multiple sclerosis, Alzheimer's disease, meningitis, and stroke (for review, see Zhao and Schwartz, 1998). These cytokines mediate inflammation and contribute to the neuropathology and pathophysiology associated with the inflamed CNS (for review, see Eng et al., 1996; Benveniste, 1997). Data from transgenic mice suggest that overexpression of IL-6 leads to reactive gliosis, neurodegeneration, breakdown of the blood-brain barrier (BBB), and angiogenesis (Campbell et al., 1993). However, other reports suggest a beneficial role of IL-6 in the CNS. Occlusion of the middle cerebral artery leads to IL- 6 bioactivity in the ischemic hemisphere, and injection of IL-6 into the ischemic region significantly reduces brain damage (Loddick et al., 1998). IL-6, in the presence of the sIL-6R, enhances neuronal survival in the absence of nerve growth factor in rat sympathetic neurons (März et al., 1998a). Our laboratory has shown that IL-6 plus the sIL-6R inhibits TNF- $\alpha$-induced expression of vascular cell adhesion molecule-1 (VCAM-1) in astrocytes (Oh et al., 1998). These studies demonstrate the need for tight regulation of IL-6 to maintain beneficial actions and prevent IL-6-induced neuropathology.

Astrocytes are the major source of IL-6 in CNS injury and inflammation (for review, see Gruol and Nelson, 1997). In vitro analysis of IL-6 production by astrocytes indicates that many stimuli can upregulate its production, in particular, the cytokines TNF- $\alpha$ and IL-1 $\beta$ (Benveniste et al., 1990, 1994). However, the role of IL-6 in its own regulation is less well defined. In this study, we have examined the role of IL-6 and the sIL-6R in IL-6 induction, with an emphasis on the ability of IL-6/sIL-6R to 
modulate TNF- $\alpha$ - and IL- $1 \beta$-induced IL-6 expression in astrocytes.

\section{MATERIALS AND METHODS}

Cell lines and primary human astrocyte cultures. The U373-MG astroglioma cell line was grown in DMEM supplemented with $10 \mathrm{mM}$ HEPES, $\mathrm{pH}$ 7.2, 2 mM L-glutamine, $100 \mathrm{U} / \mathrm{ml}$ penicillin, $100 \mu \mathrm{g} / \mathrm{ml}$ streptomycin, $0.1 \mathrm{~mm}$ nonessential amino acid mixture, $1 \mathrm{~mm}$ sodium pyruvate, and $10 \%$ fetal bovine serum (FBS), as described previously (Oh et al., 1998). CRT human astroglioma cells were grown in RPMI 1640 medium supplemented with $10 \mathrm{~mm}$ HEPES, $\mathrm{pH} 7.2,2 \mathrm{mM}$ L-glutamine, $100 \mathrm{U} / \mathrm{ml}$ penicillin, $100 \mu \mathrm{g} / \mathrm{ml}$ streptomycin, and $10 \%$ FBS as described previously (Rosenman et al., 1995). Biopsy material from patients undergoing surgery to treat intractable epilepsy was used to prepare human adult astrocyte cultures as described previously (Barnum et al., 1992). Primary human adult astrocytes were obtained after $30 \mathrm{~d}$ in culture and were grown in DMEM, high glucose formula supplemented with $2 \mathrm{~mm}$ L-glutamine, $0.1 \mathrm{~mm}$ nonessential amino acid mixture, $0.1 \%$ gentamicin, $2.5 \mu \mathrm{g} / \mathrm{ml}$ amphotericin B, and 10\% FBS. Astrocytes were $87-90 \%$ GFAP positive (Barnum et al., 1992). Human astrocytes obtained from this source have many of the same functional responses as do primary cultures of rat astrocytes (Benveniste et al., 1994; Oh et al., 1998).

Reagents. Human recombinant TNF (rTNF)- $\alpha\left(9.0 \times 10^{7} \mathrm{U} / \mathrm{mg}\right)$ and human rIL-1 $\beta\left(2.0 \times 10^{8} \mathrm{U} / \mathrm{mg}\right)$ were purchased from Genzyme (Cambridge, MA), and human rIL-6 $\left(7.0 \times 10^{3} \mathrm{U} / \mu \mathrm{g}\right)$, sIL-6R $\alpha[100$ active units $(\mathrm{AU}) / \mu \mathrm{g}]$, rTGF- $\beta_{1}\left(2.5 \times 10^{4} \mathrm{U} / \mu \mathrm{g}\right), \mathrm{rOSM}\left(4.4 \times 10^{3} \mathrm{AU} / \mu \mathrm{g}\right)$, $\operatorname{rLIF}\left(8.3 \times 10^{4} \mathrm{U} / \mu \mathrm{g}\right), \operatorname{rCNTF}(10 \mathrm{AU} / \mu \mathrm{g})$, soluble $\mathrm{rCNTFR}(3.3$ $\mathrm{AU} / \mu \mathrm{g})$, and rIL-11 $\left(6.6 \times 10^{3} \mathrm{AU} / \mu \mathrm{g}\right)$ were purchased from $\mathrm{R} \& \mathrm{D}$ Systems (Minneapolis, MN). Hyper-IL-6 (H-IL-6) was the kind gift of Professor Stefan Rose-John (Universität Mainz) and was prepared as described previously (Fischer et al., 1997). Anti-human IL-6, anti-human IL-6R, and anti-human gp130 neutralizing antibodies were obtained from R \& D Systems. Purified mouse $\operatorname{IgG}_{1}$ (anti-TNP) (used as an isotype control) was purchased from PharMingen (San Diego, CA).

IL-6 production in astrocytes. U373-MG cells, CRT cells, and primary human astrocytes were resuspended in their respective media containing $10 \% \mathrm{FBS}$ and plated at $0.5 \times 10^{6}$ cells/well into six-well $(35 \mathrm{~mm})$ plates (Costar, Cambridge, MA). The cells were allowed to reach $\sim 90 \%$ confluency, media was aspirated, and fresh serum-free media was added to cells for $12 \mathrm{hr}$. After this time, cells were washed once with sterile PBS, and fresh serum-free media was added to each well. Astrocytes were treated with various reagents (TNF- $\alpha$, IL- $1 \beta$, IL-6, sIL-6R, TGF- $\beta$, CNTF, sCNTFR, LIF, and IL-11) alone or in combination for $24 \mathrm{hr}$, then supernatants were collected, centrifuged to remove contaminating cells, and stored at $-70^{\circ} \mathrm{C}$ until use.

Measurement of IL-6 activity. IL-6 activity in astrocyte culture supernatants was determined in a biological assay using the IL-6-dependent B cell hybridoma B9, as described previously (Norris and Benveniste, 1993). Briefly, B9 cells $\left(6 \times 10^{3}\right.$ cells/well $)$ were plated in 96-well microtiter plates, then serial dilutions of astrocyte-conditioned medium and recombinant human IL-6 (used as a standard) were added and incubated at $37^{\circ} \mathrm{C}$ for $72 \mathrm{hr}$. Triplicate cultures were set up for each condition. After $72 \mathrm{hr}$, B9 cell growth was assessed using the MTT assay as described previously (Norris and Benveniste, 1993). In this assay, the amount of IL- 6 in astrocyte-conditioned supernatants was determined by comparison to a recombinant human IL-6 standard in which colorimetric change versus recombinant human IL-6 concentration (picograms per milliliter) is known. The reagents used in this study to stimulate IL-6 production (TNF- $\alpha$, IL- $1 \beta$, sIL-6R, TGF- $\beta$, OSM, LIF, CNTF, SCNTFR, and IL-11) do not support B9 growth when added directly to B9 cells or when added to astrocyte cultures immediately before collecting supernatants (data not shown).

$R N A$ isolation, riboprobes, and RNase protection assay (RPA). U373-MG cells were plated at $4 \times 10^{6}$ cells per $100 \mathrm{~mm}^{2}$ dish (Costar, Cambridge, MA). Upon confluency, cells were serum-starved for $12 \mathrm{hr}$. Total cellular RNA was isolated from resulting confluent monolayers of astrocytes that had been incubated for various times with cytokines. RNA isolation was performed as described previously (Lee et al., 1997). A pGem $4 \mathrm{Z}$ plasmid containing a $349 \mathrm{bp}$ fragment corresponding to 194-542 bp of the human IL-6 cDNA was linearized with EcoRI. In vitro transcription of this linearized plasmid with T7 RNA polymerase generated an antisense probe 408 nucleotides in length (note that this probe contains a portion of the $\mathrm{pGem} 4 \mathrm{Z}$ plasmid). A pAMP-1 vector containing a fragment of the human glyceraldehyde-3-phosphate dehydrogenase (GAPDH) cDNA (corresponding to $43-531 \mathrm{bp}$ ) was linearized with
NcoI, which digests within the GAPDH cDNA insert. In vitro transcription of this linearized plasmid with T7 RNA polymerase generates a 290 bp antisense RNA probe.

In vitro transcription of riboprobes and RPA were conducted as described previously (Lee and Benveniste, 1996). Total RNA $(15 \mu \mathrm{g})$ was hybridized with IL-6 $\left(30 \times 10^{3} \mathrm{cpm}\right)$ and GAPDH $\left(25 \times 10^{3} \mathrm{cpm}\right)$ riboprobes at $42^{\circ} \mathrm{C}$ overnight. The hybridized mixture was then treated with RNase A/T1 (1:200 dilution) at room temperature for $1 \mathrm{hr}$ and analyzed by $5 \%$ denaturing ( $8 \mathrm{M}$ urea) PAGE, and the gels were exposed to x-ray film. The protected fragments of the IL-6 and GAPDH riboprobes are 349 and 230 nucleotides in length, respectively. Quantification of protected RNA fragments was performed by PhosphorImager (Molecular Dynamics, Sunnyvale, CA). Values for IL-6 mRNA expression were normalized to GAPDH mRNA levels for each experimental condition. GAPDH mRNA was used as a control gene because its levels are not affected by cytokine treatment. The RPA shown in this article is overexposed for GAPDH because the signal for IL-6 is weaker. Quantification of the original gel was performed on a PhosphorImager to arrive at accurate values.

Nuclear run-on analysis. Nuclear run-on analysis was performed as described previously (Bethea et al., 1992; Chung et al., 1992; Shrikant et al., 1994). Nuclei were isolated from confluent monolayers of astrocytes that were incubated for $30-45 \mathrm{~min}$ in the presence or absence of stimulus (IL-6/sIL-6R, TNF- $\alpha$, IL-1 $\beta$, TNF- $\alpha+$ IL-6/sIL-6R, and IL-1 $\beta+$ IL-6/sIL-6R). The cells $\left(30 \times 10^{6}\right)$ were collected, washed once with cold PBS, and pelleted. Nuclei were isolated by lysing the cells with $10 \mathrm{~mm}$ Tris, $\mathrm{pH} 7.4,2 \mathrm{~mm} \mathrm{MgCl}_{2}, 10 \mathrm{~mm} \mathrm{NaCl}$, and $0.5 \%$ Nonidet P-40, followed by centrifugation at $1000 \times g$. The nuclei were stored at $-80^{\circ} \mathrm{C}$ in buffer containing $50 \mathrm{~mm}$ Tris, $\mathrm{pH} 8.3,40 \%$ glycerol, $5 \mathrm{mM} \mathrm{MgCl}_{2}$, and $0.1 \mathrm{~mm}$ EDTA. To perform run-on transcriptional analysis, the nuclei were thawed on ice and incubated for $30 \mathrm{~min}$ at $30^{\circ} \mathrm{C}$ in reaction buffer containing $10 \mathrm{~mm}$ DTT, $1 \mathrm{~mm}$ each of ATP, CTP and GTP, and $0.25 \mathrm{mCi}$ $\left[{ }^{32} \mathrm{P}\right] \mathrm{UTP}(3000 \mathrm{Ci} / \mathrm{mm})$ (Amersham, Arlington Heights, IL). After the reaction, DNA digestion was performed in the presence of $0.5 \mathrm{M} \mathrm{NaCl}$,

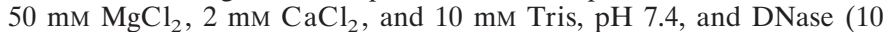
$\mathrm{mg} / \mathrm{ml}$ ) (Promega, Madison, WI) for $5 \mathrm{~min}$ at $30^{\circ} \mathrm{C}$. Protein digestion was then performed in the presence of $5 \%$ SDS, $0.5 \mathrm{~m}$ Tris, $\mathrm{pH} 7.4,0.125 \mathrm{M}$ EDTA, and proteinase $\mathrm{K}(20 \mu \mathrm{g} / \mathrm{sample})$ for $30 \mathrm{~min}$ at $42^{\circ} \mathrm{C}$. Nuclei were lysed and RNA was harvested as described in RNA isolation. Denatured circular plasmid DNA was immobilized on nitrocellulose paper using a Millipore (Bedford, MA) Milliblot S system. After UV cross-linking the DNA to the nitrocellulose, prehybridization was performed at $65^{\circ} \mathrm{C}$ for at least $3 \mathrm{hr}$ in a solution of $50 \%$ formamide, $0.1 \%$ SDS, $5 \times$ SSC, $2.5 \times$ Denhardt's, $250 \mu \mathrm{g} / \mathrm{ml}$ tRNA, and $50 \mathrm{~mm} \mathrm{Na}_{2} \mathrm{PO}_{4}, \mathrm{pH}$ 6.5. For hybridization, $9 \times 10^{6} \mathrm{cpm}$ of labeled and denatured RNA was used in $1 \mathrm{ml}$ of hybridization solution and incubated at $65^{\circ} \mathrm{C}$ for $48 \mathrm{hr}$. The filters were washed twice for $30 \mathrm{~min}$ at $65^{\circ} \mathrm{C}$ in $2 \times \mathrm{SSC}, 30 \mathrm{~min}$ at $37^{\circ} \mathrm{C}$ in $2 \times \mathrm{SSC}$ with $10 \mu \mathrm{g} / \mathrm{ml}$ ribonuclease $\mathrm{A} / \mathrm{T} 1$, and finally for $30 \mathrm{~min}$ at $37^{\circ} \mathrm{C}$ in $2 \times$ SSC. The filters were exposed to the PhosphorImager (Molecular Dynamics) for quantification. The increase of transcriptional activation was determined by comparing the ratios of IL-6/GAPDH values obtained for each stimulus.

Statistical analysis. Significance between experimental values was determined using two-way ANOVA. ${ }^{*} p<0.05$, ${ }^{* *} p<0.01$, and ${ }^{* * *} p<$ 0.001 .

\section{RESULTS}

\section{Treatment of U373-MG cells with TNF- $\alpha$ and the sIL- $6 R$ induces IL-6 production}

We were interested in determining the role of IL-6 and the sIL-6R (IL-6/sIL-6R) in its own regulation. Because of the obvious difficulty of measuring IL-6 protein production in the presence of exogenously added IL-6, an endogenous source of IL-6 was used for initial studies. Previously, our laboratory has shown that IL- 6 protein secretion is upregulated by TNF- $\alpha$ in primary rat astrocytes (Benveniste et al., 1990). To determine whether similar IL-6 induction is seen in the human glioma cell line U373-MG, cells were treated with TNF- $\alpha$ (50 ng/ml) for $24 \mathrm{hr}$, and supernatants were analyzed for IL- 6 protein secretion by the B9 bioassay. This concentration of TNF- $\alpha$ was previously determined to be optimal for IL-6 production by astrocytes (Oh et al., 1998). Constitutively, U373-MG cells express low levels of IL-6 
A.

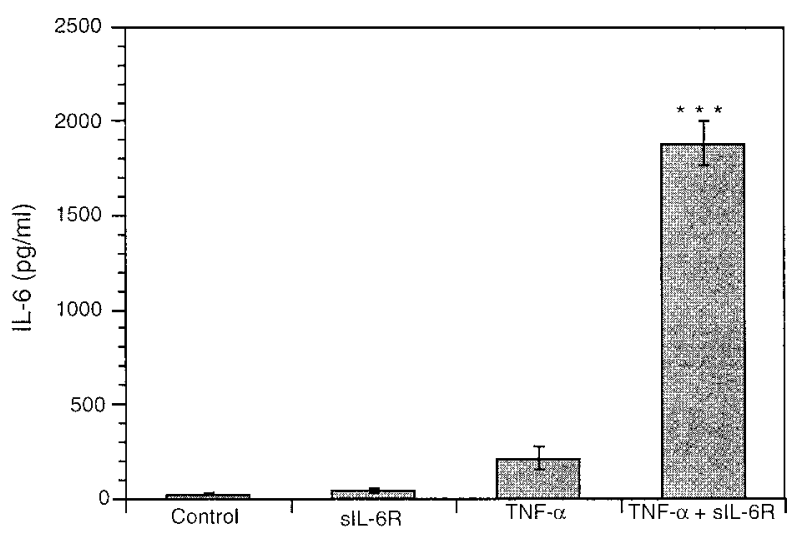

B.

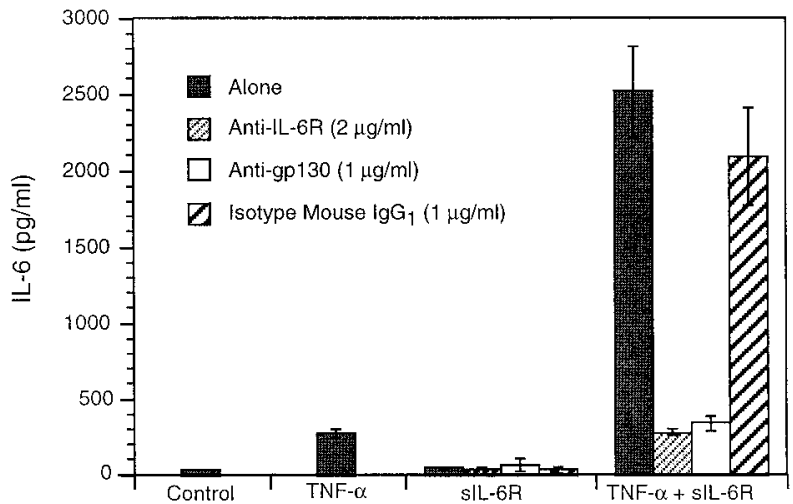

C.

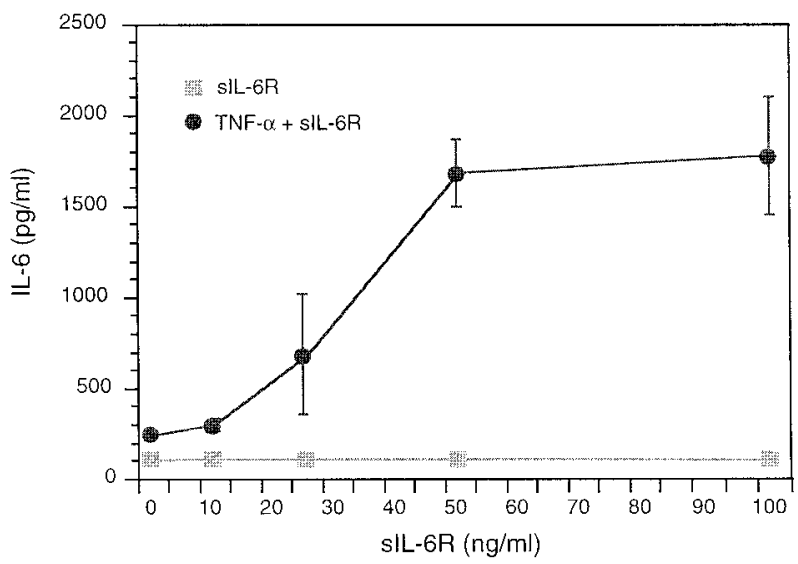

Figure 1. Stimulation of IL-6 bioactivity in U373-MG cells by TNF- $\alpha$ and the soluble IL-6 receptor. U373-MG cells were incubated with TNF- $\alpha(50 \mathrm{ng} / \mathrm{ml})$ and the sIL-6R $(100 \mathrm{ng} / \mathrm{ml})$ alone and in combination for $24 \mathrm{hr}$, and supernatants harvested and then analyzed for IL-6 activity as described in Materials and Methods. ${ }^{* *} p<0.001(A)$. Neutralizing antibodies to the IL-6R $(2 \mu \mathrm{g} / \mathrm{ml})$ were preincubated with sIL-6R for 30 min at room temperature after which it was added to U373-MG cells alone or in combination with TNF- $\alpha$, or U373-MG cells were preincubated for $30 \mathrm{~min}$ at room temperature with neutralizing antibodies to gp130 $(1 \mu \mathrm{g} / \mathrm{ml})$, then TNF- $\alpha$, sIL-6R, or TNF- $\alpha+$ sIL-6R were added to the cells. Supernatants were analyzed for IL-6 activity $(B)$. Cells were treated with TNF- $\alpha$ alone $(50 \mathrm{ng} / \mathrm{ml})$, TNF- $\alpha$ plus increasing concentrations of the sIL-6R $(0-100 \mathrm{ng} / \mathrm{ml})$, or sIL-6R alone $(C)$. Results are the mean \pm SD of three experiments analyzed in triplicate.

protein, and after $24 \mathrm{hr}$ of stimulation with TNF- $\alpha$, IL-6 protein levels in supernatants increased by $\sim 10$-fold, reaching levels over $200 \mathrm{pg} / \mathrm{ml}$ (Fig. 1A). To determine whether endogenous IL-6, induced by TNF- $\alpha$, could complex with exogenous sIL-6R and
Table 1. IL-6 induction in human astrocytes and CRT cells by TNF- $\alpha$ and the sIL-6R

\begin{tabular}{lcc} 
& \multicolumn{2}{l}{ IL-6 bioactivity $(\mathrm{pg} / \mathrm{ml})$} \\
\cline { 2 - 3 } Cell treatment $^{a}$ & Astrocytes & CRT \\
\hline Medium & $0.6 \pm 0.4^{b}$ & $1.3 \pm 0.1^{b}$ \\
sIL-6R $(100 \mathrm{ng} / \mathrm{ml})$ & $2.0 \pm 0.9$ & $3.2 \pm 0.6$ \\
TNF- $\alpha(50 \mathrm{ng} / \mathrm{ml})$ & $221.6 \pm 37.3$ & $244.4 \pm 76.7$ \\
TNF- $\alpha+$ sIL-6R & $29,793.4 \pm 10,568.0^{c, *}$ & $1,626.7 \pm 345.1^{c, * *}$
\end{tabular}

${ }^{a}$ Twenty-four hour incubation period.

${ }^{b}$ Mean \pm SD of triplicate samples from two experiments analyzed in triplicate.

${ }^{c}$ Significance between experimental values was determined by two-way ANOVA: ${ }^{*} p<0.05 ;{ }^{* *} p<0.01$.

affect IL-6 secretion, U373-MG cells were treated with sIL-6R $(100 \mathrm{ng} / \mathrm{ml})$ alone or in combination with TNF- $\alpha$ for $24 \mathrm{hr}$, and supernatants were analyzed for IL-6 secretion. Treatment with the sIL-6R alone did not increase IL-6 expression in U373-MG cells; however, co-stimulation with TNF- $\alpha$ and the sIL-6R significantly increased IL-6 protein levels in the supernatants to $\sim 1900$ $\mathrm{pg} / \mathrm{ml}$ (Fig. 1A), indicating a synergistic interaction between TNF- $\alpha$ and the sIL-6R. Identical experiments have been performed on human adult primary astrocytes and the human astroglioma cell line CRT (Table 1). In all cases, results are qualitatively similar, suggesting that this effect is not specific to U373-MG cells but extends to all astrocyte sources thus far tested.

Addition of neutralizing antibodies to the IL-6R and gp130 blocked induction of IL- 6 in the presence of TNF- $\alpha$ and the sIL-6R, reducing levels to those seen on treatment with TNF- $\alpha$ alone (Fig. 1B). Addition of an isotype-matched antibody did not affect IL-6 expression by U373-MG cells in the presence of TNF- $\alpha$ and the sIL-6R (Fig. 1B). Taken together, these data show that the significant increase of IL-6 in the presence of TNF- $\alpha$ and the sIL-6R is specific to the sIL-6R and requires gp130. As well, induction of IL-6 by the sIL-6R in the presence of TNF- $\alpha$ is dose dependent, with maximal responses observed using $50-100 \mathrm{ng} / \mathrm{ml}$ of sIL-6R (Fig. 1C). The concentration of 100 $\mathrm{ng} / \mathrm{ml}$ was used for all subsequent experiments.

\section{Effect of TNF- $\alpha$ and IL-6/sIL-6R on IL- 6 mRNA levels}

To directly examine the role of IL-6/sIL-6R in IL-6 regulation, analysis was performed at the mRNA level. U373-MG cells were incubated in the presence of exogenous IL-6 $(5 \mathrm{ng} / \mathrm{ml})$ and the sIL-6R (100 ng/ml), and RNA was isolated at the indicated times and analyzed by RPA. Results indicate that IL-6/sIL-6R treatment has a modest effect on IL-6 mRNA, raising levels approximately fourfold above constitutive expression at $1 \mathrm{hr}$ and declining thereafter (Fig. 2). IL-6 at a concentration of $5 \mathrm{ng} / \mathrm{ml}$ was determined in a dose-response experiment to be optimal for IL-6 induction in the presence of $100 \mathrm{ng} / \mathrm{ml}$ of the sIL-6R (data not shown). Similar time course analysis was performed on U373-MG cells treated with TNF- $\alpha$. TNF- $\alpha$-induced IL- 6 mRNA also peaked at $1 \mathrm{hr}$, with levels approximately eightfold above constitutive levels and declining thereafter (Fig. 2). On treatment of U373-MG cells with TNF- $\alpha$ plus IL-6/sIL-6R, IL-6 mRNA levels reached $\sim 12$-fold at $1 \mathrm{hr}$; this reflects an additive effect of TNF- $\alpha$ and IL-6/sIL-6R. However, at $6 \mathrm{hr}$, samples treated with TNF- $\alpha$ plus IL-6/sIL-6R were significantly elevated $(\sim 15$-fold induction), although the levels induced by IL-6/sIL-6R or TNF- $\alpha$ alone were quite low (Fig. 2). These data indicate that IL-6 mRNA levels at $1 \mathrm{hr}$ are increased in the presence of TNF- $\alpha$ plus 


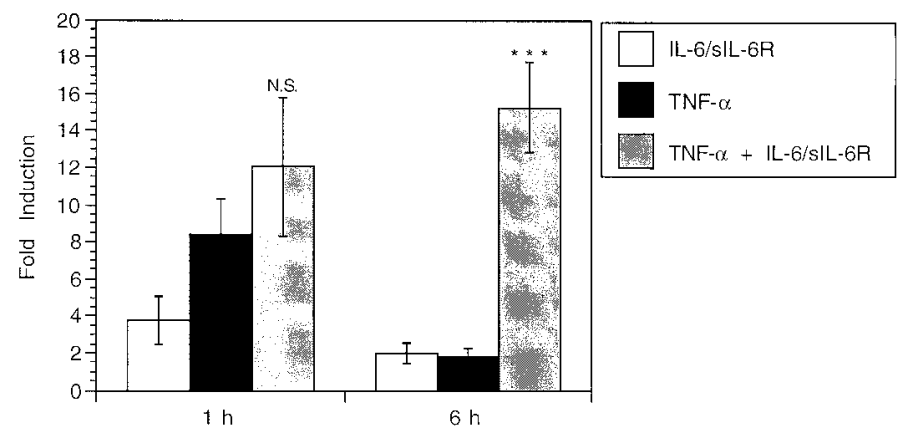

Figure 2. IL- 6 mRNA induction by IL-6/sIL-6R and TNF- $\alpha$ alone and in combination. U373-MG cells were treated with IL-6 $(5 \mathrm{ng} / \mathrm{ml}) / \mathrm{sIL}-6 \mathrm{R}$ $(100 \mathrm{ng} / \mathrm{ml})$, TNF- $\alpha(50 \mathrm{ng} / \mathrm{ml})$, or both, for 1 or $6 \mathrm{hr}$. RNA was extracted and examined by RPA for IL-6 and GAPDH mRNA expression. PhosphorImager quantification of the blots was performed, and data were normalized to GAPDH expression and represented as fold induction above constitutive IL- 6 expression. Results are the mean \pm SD of three experiments. ${ }^{* *} p<0.001 ; N . S$., not significant.

IL-6/sIL-6R over treatment with either factor alone and remain elevated at $6 \mathrm{hr}$.

\section{IL-6 is required for the synergistic induction seen in the presence of TNF- $\alpha$ and sIL-6R}

We speculated that endogenous IL- 6 , induced by TNF- $\alpha$, could complex with exogenous sIL-6R and affect IL-6 secretion. On treatment of U373-MG cells with TNF- $\alpha$ plus the sIL-6R, highlevel expression of IL-6 protein was seen (Fig. 1). However, we have not shown the absolute necessity for IL-6 in this response. To address this issue, U373-MG cells were treated with TNF- $\alpha$ plus sIL-6R or TNF- $\alpha$ plus IL-6/sIL-6R for $6 \mathrm{hr}$, and IL-6 mRNA expression was analyzed by RPA. As shown previously, IL-6/sIL-6R or TNF- $\alpha$ stimulation induces a modest increase in IL-6 mRNA expression at $6 \mathrm{hr}$ (Fig. 3A, lanes 4 and 5). Addition of IL- 6 plus TNF- $\alpha$ does not affect IL- 6 mRNA compared with TNF- $\alpha$ alone (compare lanes 5 and 6 ). Inclusion of IL-6/sIL-6R plus TNF- $\alpha$ induces a synergistic increase in IL-6 mRNA expression (lane 9), and the addition of neutralizing antibody to IL-6 abrogates this response (lane 10). As well, addition of sIL-6R plus TNF- $\alpha$ enhances IL- 6 mRNA expression over that seen with TNF- $\alpha$ alone (compare lanes 5 and 7), and neutralizing antibody to IL-6 blocks this effect (lane 8). Quantification is shown in Figure $3 B$. These results provide evidence that endogenous or exogenous IL-6 is required to complex with the sIL-6R to initiate signaling.

To further characterize this response, the ability of Hyper-IL-6 (H-IL-6) to induce IL-6 mRNA expression alone and in combination with TNF- $\alpha$ was compared with IL-6/sIL-6R treatment in U373-MG cells. H-IL-6 is a recombinant protein composed of the functional domains of IL-6 and the IL-6R. It has been shown to have greater bioactivity than IL- 6 and sIL-6R added separately (Fischer et al., 1997). As demonstrated by RPA, H-IL-6 (10 $\mathrm{ng} / \mathrm{ml}$ ) is a slightly better inducer of IL-6 mRNA than IL-6 plus sIL-6R (Fig. 3C). Co-treatment of U373-MG cells with TNF- $\alpha$ and H-IL-6 led to $\sim 27$-fold increase over unstimulated cells, whereas treatment with TNF- $\alpha$ and IL-6/sIL-6R gave an $\sim 18$ fold increase (Fig. 3C).

\section{IL-1 $\beta$, but not TGF- $\beta$, synergizes with sIL-6R to enhance IL-6 expression}

Inducers of IL- 6 in astrocytes include the proinflammatory cytokines TNF- $\alpha$ and IL- $\beta$ and the anti-inflammatory cytokine
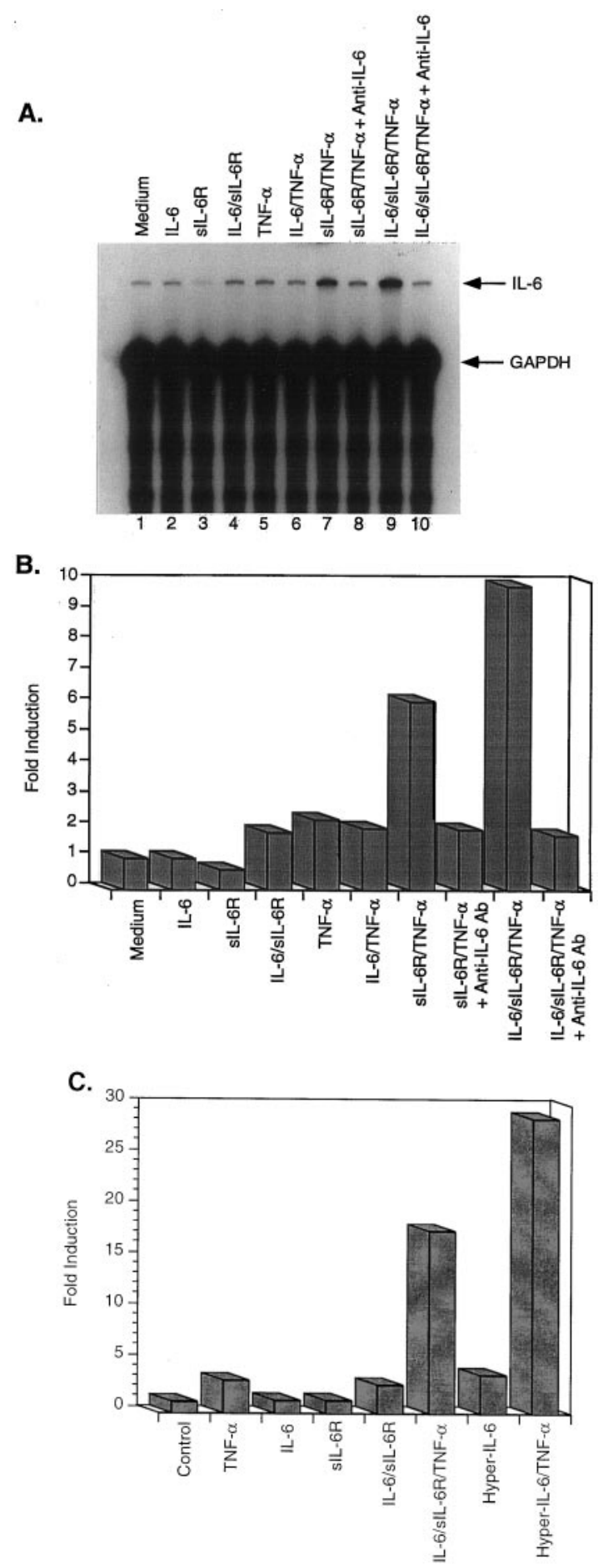

Figure 3. TNF- $\alpha$, the sIL-6R, and endogenous or exogenous IL-6 induce IL-6 mRNA expression. U373-MG cells were treated with TNF- $\alpha$ (50 $\mathrm{ng} / \mathrm{ml})$, sIL-6R (100 ng/ml), IL-6 (5 ng/ml), or anti-IL-6 neutralizing antibody $(1 \mu \mathrm{g} / \mathrm{ml})$ alone and in various combinations for $6 \mathrm{hr}$. RNA was extracted and examined by RPA for IL- 6 and GAPDH mRNA expression $(A)$. PhosphorImager quantification of the blot is shown in $B$. Data have been normalized to GAPDH expression and are represented as fold induction above constitutive IL-6 expression (lane 1, Medium). These data are representative of two experiments. Cells were treated with TNF- $\alpha$, IL-6, sIL-6R, or H-IL-6 (10 ng/ml) alone and in various combinations for $6 \mathrm{hr}$. RNA was analyzed for IL-6 mRNA as described above $(C)$. Data have been normalized to GAPDH expression and are represented as fold induction above constitutive IL-6 expression. These data are representative of two experiments. 
Table 2. IL-6 induction by TNF- $\alpha$, IL-1 $\beta$, and TGF- $\beta$ in the presence of the sIL-6R

IL-6 bioactivity $(\mathrm{pg} / \mathrm{ml})$

\begin{tabular}{lcc} 
Cell treatment & \multicolumn{1}{c}{ Alone } & +sIL-6R $(100 \mathrm{ng} / \mathrm{ml})$ \\
\hline Medium & $21.4 \pm 4.4^{b}$ & $38.1 \pm 13.1$ \\
TNF- $\alpha(50 \mathrm{ng} / \mathrm{ml})$ & $210.6 \pm 61.4$ & $1,885.3 \pm 116.6^{c, * * *}$ \\
TGF- $\beta_{1}(10 \mathrm{ng} / \mathrm{ml})$ & $184.4 \pm 40.3$ & $333.0 \pm 157.8^{\text {N.S. }}$ \\
IL- $\beta(2 \mathrm{ng} / \mathrm{ml})$ & $23,275.6 \pm 5,334.4$ & $1,000,667.0 \pm 25,807.9^{c, * * *}$
\end{tabular}

${ }^{a}$ Twenty-four hour incubation period.

${ }^{b}$ Mean $\pm \mathrm{SD}$ of three experiments analyzed in triplicate.

${ }^{c} p$ values for cytokine versus cytokine + sIL-6R treated samples: ${ }^{* * *} p<0.001$. N.S., Not significant.

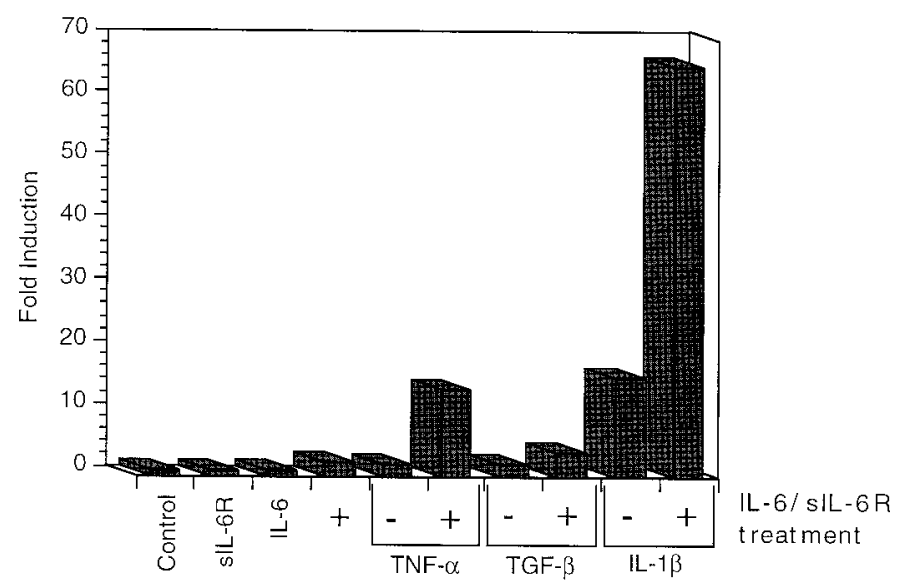

Figure 4. TNF- $\alpha$ and IL-1 $\beta$, but not TGF- $\beta$, synergize with IL-6/sIL-6R for IL-6 mRNA expression. U373-MG cells were treated with TNF- $\alpha$ (50 $\mathrm{ng} / \mathrm{ml})$, TGF- $\beta(10 \mathrm{ng} / \mathrm{ml})$, or IL- $\beta(2 \mathrm{ng} / \mathrm{ml})$ alone and in combination with IL-6 $(5 \mathrm{ng} / \mathrm{ml})$ and the sIL-6R $(100 \mathrm{ng} / \mathrm{ml})$ for $6 \mathrm{hr}$. RNA was extracted and examined by RPA for IL-6 and GAPDH mRNA expression. PhosphorImager quantification of the blot is shown. Data have been normalized to GAPDH expression and are represented as fold induction above constitutive IL-6 expression. These data are representative of two experiments.

TGF- $\beta$ (Benveniste et al., 1990, 1994). Therefore, studies were extended to determine whether similar synergy with the sIL-6R would be seen with these other inducers of IL-6. A $24 \mathrm{hr}$ incubation in the presence of IL-1 $\beta(2 \mathrm{ng} / \mathrm{ml})$ or TGF- $\beta(10 \mathrm{ng} / \mathrm{ml})$ alone or in combination with the sIL-6R revealed that IL- $1 \beta$ is a potent inducer of IL- 6 and, as well, that synergy does occur with this cytokine and the sIL-6R (Table 2). The levels of IL-1 $\beta$ induction are specific to IL- $1 \beta$, because the addition of the IL-1 receptor antagonist (IL-1RA, $100 \mathrm{ng} / \mathrm{ml}$ ) blocked IL-1 $\beta$ induction (data not shown). TGF- $\beta$ alone induced expression of IL- 6 to levels similar to those seen for $\mathrm{TNF}-\alpha$; however, significant increases were not seen on addition of the sIL-6R (Table 2). Analysis at the mRNA level correlated with the results obtained for IL- 6 protein levels. Both TNF- $\alpha$ and IL- $1 \beta$ synergized with IL-6/sIL-6R to increase IL-6 mRNA expression, whereas TGF- $\beta$ did not (Fig. 4).

\section{TNF- $\alpha$ - and IL-1 $\beta$-induced IL-6 message is not stabilized by the addition of IL-6/sIL-6R}

To determine whether the synergy between TNF- $\alpha$ or IL- $1 \beta$ and IL-6/sIL-6R on IL-6 mRNA expression was occurring at the transcriptional or post-transcriptional level, $t_{1 / 2}$ experiments were performed to assess the stability of the IL-6 message. U373-MG cells were incubated with TNF- $\alpha$, IL-6/sIL-6R, or TNF- $\alpha$ plus IL-6/sIL-6R for $6 \mathrm{hr}$, then actinomycin D (ACT-D; $5 \mu \mathrm{g} / \mathrm{ml}$ ) was added for an additional 30-120 min. RNA was isolated at the indicated time points and analyzed for IL- 6 and GAPDH mRNA levels by RPA. As shown in Figure $5 A$, the $t^{1 / 2}$ of IL- 6 mRNA induced by IL-6/sIL-6R was $\sim 30 \mathrm{~min}$, that for TNF- $\alpha$-induced IL-6 was $\sim 90 \mathrm{~min}$, and that of TNF- $\alpha$ plus IL-6/sIL-6R-induced IL-6 mRNA was $\sim 30 \mathrm{~min}$. These results indicate that IL-6/ sIL-6R does not promote stabilization of TNF- $\alpha$-induced IL-6 message. Identical results were obtained when IL-6 message stability was assessed after a 1 hr stimulation with TNF- $\alpha$, IL-6/ sIL-6R, or TNF- $\alpha$ plus IL-6/sIL-6R (data not shown). Comparable experiments were performed with IL-1 $\beta$ as the stimulus. We initially assessed IL- 6 steady-state mRNA levels induced by IL- $1 \beta$ in the absence or presence of IL-6/sIL-6R at 1 and $6 \mathrm{hr}$. As shown in Figure $5 B$, IL- $1 \beta$ induced an approximately sevenfold induction of IL-6 mRNA at $1 \mathrm{hr}$, and inclusion of IL-6/sIL-6R increased induction to $\sim 17$-fold. After a $6 \mathrm{hr}$ incubation, IL-1 $\beta$ treatment induced a $\sim 25$-fold increase, and addition of IL-6/ sIL-6R led to a further increase to $\sim 69$-fold (Fig. $5 B$ ). These findings with IL- $1 \beta$ differ from those using TNF- $\alpha$ as the stimulus (Fig. 2); in those experiments, peak IL-6 mRNA expression was seen after a $1 \mathrm{hr}$ treatment with $\mathrm{TNF}-\alpha$, with levels declining thereafter. We next assessed IL- 6 message stability in the presence of IL- $1 \beta$ or IL-6/sIL-6R, or both, after a 1 or 6 hr stimulation period. The $t_{1 / 2}$ of IL- 6 message induced by a $1 \mathrm{hr}$ stimulation with IL- $1 \beta$ was $\sim 60 \mathrm{~min}$, and that of IL-1 $\beta$ plus IL-6/sIL-6Rinduced mRNA was $\sim 30 \mathrm{~min}$ (Fig. $5 C$ ). Thus, IL-6/sIL-6R does not enhance the stabilization of IL- $1 \beta$-induced IL- 6 message. When the stimulation period with IL- $1 \beta$ was extended to $6 \mathrm{hr}$, a different pattern of IL- 6 mRNA stability emerged. The $t_{1 / 2}$ of IL- $1 \beta$-induced IL- 6 mRNA was $>18 \mathrm{hr}$, because there was no degradation of IL-6 message during this time period (Fig. $5 D$ ). The inclusion of IL-6/sIL-6R did not affect the $t_{1 / 2}$ of IL- $1 \beta$ induced IL-6 message (Fig. 5D). These results indicate that (1) IL- $1 \beta$ stimulation for a prolonged time period $(6 \mathrm{hr})$ promotes stabilization of the IL-6 message, and (2) IL-6/sIL-6R treatment likely does not influence IL-1 $\beta$-induced IL- 6 gene expression at the post-transcriptional level.

\section{Enhancement of TNF- $\alpha$ - and IL-1 $\beta$-induced IL-6 expression by IL-6/sIL-6R is transcriptional}

Our results examining the increase in IL-6 mRNA expression after a $1 \mathrm{hr}$ stimulation with TNF- $\alpha$, TNF- $\alpha$ plus IL-6/sIL-6R, IL- $1 \beta$, or IL- $1 \beta$ plus IL-6/sIL-6R indicate that the effect is not post-transcriptional (Fig. $5 A, C$ ), suggesting an influence at the transcriptional level. Nuclear run-on analysis was performed on U373-MG cells treated with the above-mentioned factors alone and in combination for 30-45 min. The nuclei were isolated, and the RNA transcripts that had been initiated were allowed to complete in the presence of $\left[{ }^{32} \mathrm{P}\right] \mathrm{UTP}$. Labeled RNA transcripts were then hybridized to slot-blotted cDNA encoding human IL-6, human GAPDH, or DNA vector as a negative control. The levels of IL-6 transcription were normalized to that of GADPH. As shown in Figure 6, IL-6/sIL-6R treatment induced IL-6 transcription by $\sim 5.8$-fold, TNF- $\alpha$ by $\sim 6$.7-fold, and IL- $1 \beta$ by $\sim 13.3$-fold. Synergistic increases in IL-6 transcription were observed in the presence of TNF- $\alpha$ plus IL-6/sIL-6R ( $\sim 36.8$-fold induction) or IL- $1 \beta$ plus IL-6/sIL-6R ( $\sim 45.9$-fold induction). These results support the hypothesis that enhancement of TNF- $\alpha$ - and IL- $1 \beta$ induced IL-6 gene expression by IL-6/sIL-6R is transcriptional. 
A.

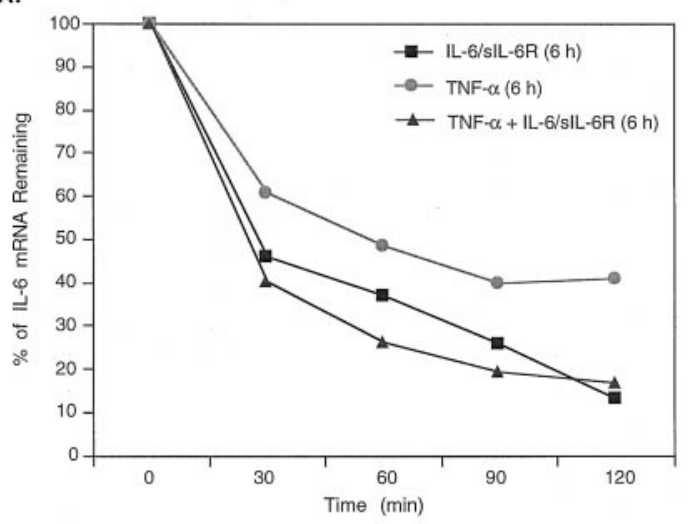

B.

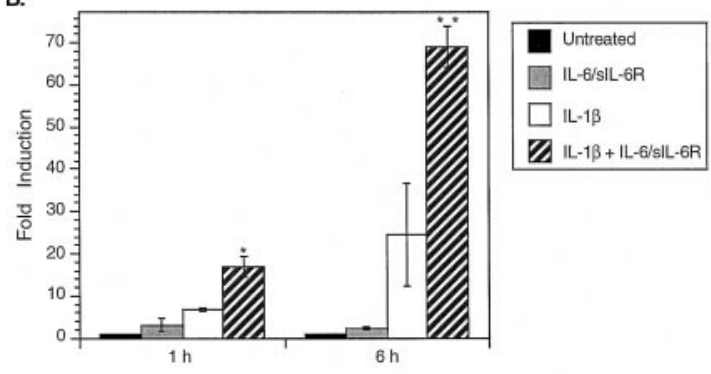

c.

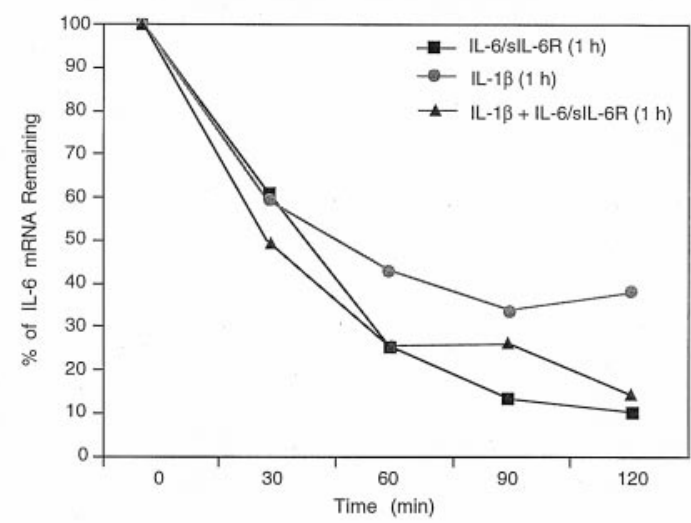

D.

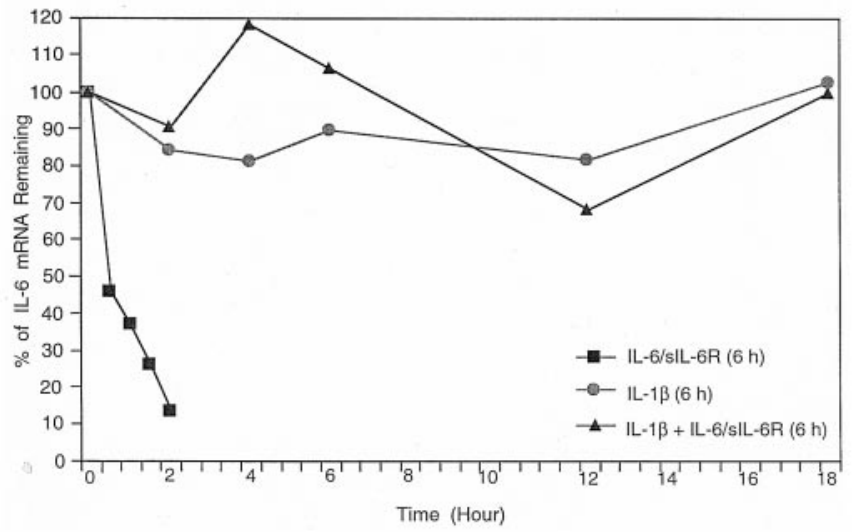

Figure 5. IL-6/sIL-6R does not affect TNF- $\alpha$ - or IL-1 $\beta$-induced IL-6 mRNA stability. U373-MG cells were incubated with TNF- $\alpha$, IL-6/sIL$6 \mathrm{R}$, and TNF- $\alpha$ plus IL-6/sIL-6R for $6 \mathrm{hr}$, then actinomycin D (ACT-D; $5 \mu \mathrm{g} / \mathrm{ml}$ ) was added, cells were harvested at the indicated times, and RNA was subjected to RPA for IL-6 and GAPDH mRNA. IL- 6 mRNA at time 0 (before the addition of ACT-D) was plotted as $100 \%$. The average of two experiments is presented $(A)$. Cells were incubated with medium,

\section{Regulation of IL- 6 by other members of the IL- 6 cytokine family}

Members of the IL-6 family are known to elicit redundant responses (for review, see Taga and Kishimoto, 1997); therefore, we were interested in determining whether OSM, CNTF plus the soluble CNTF receptor, LIF, or IL-11 had the capacity to regulate IL-6 expression in U373-MG cells. Cells were treated for 24 hr with the above-mentioned cytokines alone or in combination with TNF- $\alpha$, and supernatants were isolated and analyzed for IL-6 bioactivity as described previously. OSM and LIF alone were able to induce IL-6 bioactivity. In combination with TNF- $\alpha$, OSM induced high levels of IL-6, similar to levels seen on treatment with TNF- $\alpha$ and the sIL-6R (Fig. 7). LIF did not function in a synergistic manner with TNF- $\alpha$ for enhanced IL-6 expression, whereas CNTF/sCNTFR and IL-11 had no significant effect either alone or with TNF- $\alpha$ (Fig. 7). Comparable results were obtained using human adult astrocytes and CRT astroglioma cells (data not shown).

\section{DISCUSSION}

IL-6 has been shown to have beneficial potential in the CNS because of its neurotrophic and neuroprotective effects (Satoh et al., 1988; Hama et al., 1989; Gadient and Otten, 1997; Loddick et al., 1998; März et al., 1998b), and anti-inflammatory actions through the inhibition of VCAM-1, intercellular adhesion molecule-1, and TNF- $\alpha$ expression by CNS cells (Benveniste et al., 1995; Shrikant et al., 1995; Oh et al., 1998). However, other reports suggest that IL- 6 is detrimental and adds to the pathophysiology associated with CNS disorders (Campbell et al., 1993; Klein et al., 1997). Collectively, these studies illustrate the pleiotropic nature of IL- 6 in the CNS and stress the need for an understanding of IL-6 regulation in the CNS. Previously, we have shown that human astrocytes express low levels of the IL-6R and require the addition of the sIL-6R for IL-6-mediated responses (Oh et al., 1998). Herein, we have shown that treatment of astrocytes with IL-6 and the sIL-6R leads to modest increases in IL-6 mRNA expression. However, co-treatment with either TNF- $\alpha$ or IL- $1 \beta$ plus IL-6/sIL-6R leads to synergistic increases in IL-6 gene expression.

We speculated that TNF- $\alpha$ stimulation of astrocytes would provide a source of endogenous IL- 6 that would then interact with the sIL-6R and possibly influence IL-6 expression. The addition of TNF- $\alpha$ and the sIL-6R led to synergistic increases in IL-6 expression by U373-MG cells, primary human astrocytes, and CRT cells (Fig. 1, Table 1). These results suggest that the sIL-6R plays a pivotal role in determining the levels of IL-6 expressed by astrocytes in the CNS and furthermore influences IL-6 function in the CNS. This is supported by several reports that CNS cells that are normally slightly responsive or unresponsive to IL- 6 become responsive on addition of the sIL-6R. In the absence of nerve growth factor, IL-6 weakly enhances sympa-

$\leftarrow$

IL-1 $\beta$ (2 ng/ml) or IL-6/sIL-6R, or both, for 1 or $6 \mathrm{hr}$. PhosphorImager quantification of the blots was performed, and data were normalized to GAPDH expression and represented as fold induction above constitutive IL-6 expression. Results are the mean \pm SD of two experiments. ${ }^{*} p<$ $0.05 ; * p<0.01(B)$. U373-MG cells were incubated with IL-1 $\beta$, IL-6/ sIL-6R, and IL- $1 \beta$ plus IL-6/sIL-6R for $1 \mathrm{hr}(C)$ or $6 \mathrm{hr}(D)$, then ACT-D was added, cells were harvested at the indicated times, and RNA was analyzed for IL-6 and GAPDH mRNA. IL- 6 mRNA at time 0 (before the addition of ACT-D) was plotted as $100 \%$. The average of two experiments is presented. 


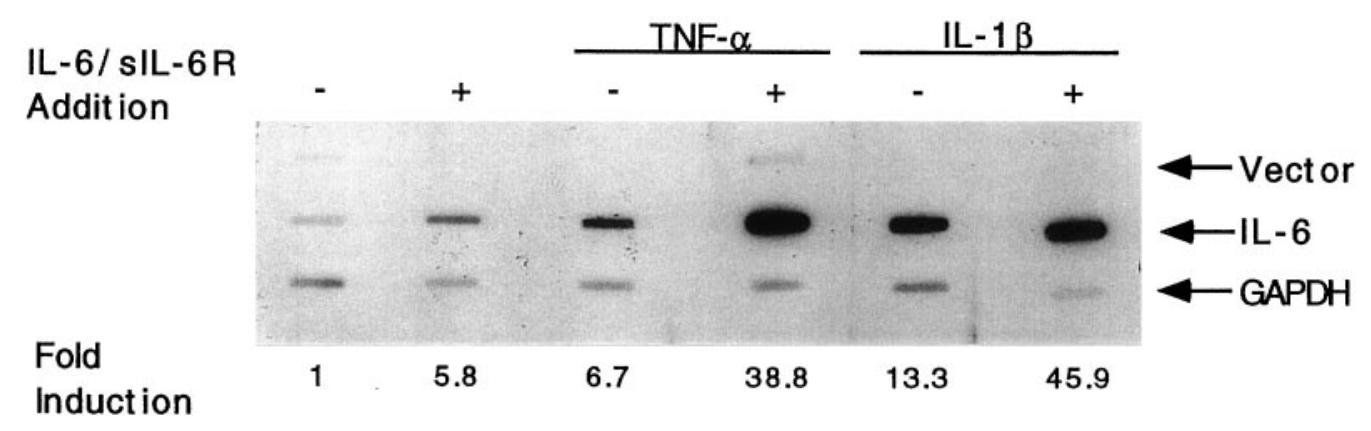

Figure 6. IL-6 transcription in the presence of TNF- $\alpha$, IL-1 $\beta$, and IL-6/sIL-6R. U373-MG cells were incubated in the presence of medium, TNF- $\alpha$, IL-1 $\beta$, and IL-6/sIL-6R alone and in combination for 30-45 min. Labeled transcripts were prepared as described in Materials and Methods and hybridized to filters containing $5 \mu \mathrm{g}$ of nonspecific DNA, human IL-6 cDNA, or human GAPDH cDNA. The blots were exposed to the PhosphorImager, and IL- 6 values were normalized to the value of GAPDH for each sample. These data are representative of two experiments.

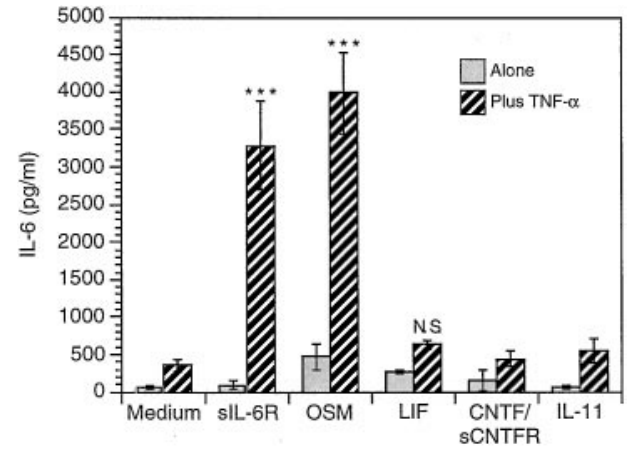

Figure 7. Stimulation of IL-6 bioactivity in U373-MG cells by IL-6 family members. U373-MG cells were incubated with sIL-6R (100 ng/ml), OSM (10 ng/ml), LIF (50 ng/ml), CNTF (100 ng/ml) plus sCNTFR (100 $\mathrm{ng} / \mathrm{ml})$, and IL-11 $(50 \mathrm{ng} / \mathrm{ml})$ alone and in combination with TNF- $\alpha(50$ $\mathrm{ng} / \mathrm{ml}$ ) for $24 \mathrm{hr}$, and supernatants were harvested and then analyzed for IL-6 activity as described in Materials and Methods. Results are the mean $\pm \mathrm{SD}$ of three experiments analyzed in triplicate. ${ }^{* * *} p<0.001$; N.S., not significant.

thetic neuron survival, and the addition of the sIL-6R enhances neuronal survival (März et al., 1998a). In human astrocytes, IL-6 alone has no effect on $\alpha_{1}$-antichymotrypsin expression, whereas addition of the sIL-6R leads to expression (Kordula et al., 1998). In the presence of the sIL-6R, IL- 6 inhibits TNF- $\alpha$-induced VCAM-1 expression in astrocytes (Oh et al., 1998). These findings suggest that the sIL-6R is a functionally relevant CNS molecule. In this regard, sIL-6R is detectable in the CSF of normal individuals $(0.8-1.67 \mathrm{ng} / \mathrm{ml})$ (Frieling et al., 1994; RoseJohn and Heinrich, 1994), although the source of sIL-6R in the CNS is unknown. A likely source of CNS sIL-6R is Purkinje neurons, which exhibit intense immunostaining for the IL-6R (Nelson et al., 1999). As well, IL-6R immunoreactivity has been detected in hypoglossal nerve cell bodies in the brainstem and in dorsal root ganglion neurons (Hirota et al., 1996; Thier et al., 1999). Other potential CNS sources of sIL-6R, particularly under inflammatory conditions, are activated macrophages and T-cells (Müllberg et al., 1993; Banning et al., 1998; Jones et al., 1998). Preliminary results from our laboratory indicate that sIL-6R, in the range of $300-900 \mathrm{pg} / \mathrm{ml}$, can be detected from human brain extracts (our unpublished observation). Circulating levels of sIL-6R are considerably higher $(\sim 70 \mathrm{ng} / \mathrm{ml})$ and may increase CNS levels on disruption of the $\mathrm{BBB}$, thereby providing an endogenous CNS source of sIL-6R sufficient to elicit functional responses.
Addition of TNF- $\alpha$ plus IL-6/sIL-6R led to an increase in the overall level of IL-6 mRNA as well as the duration of expression (Fig. 2). To determine the basis of this increase, mRNA stability assays were performed. As shown in Figure $5 A$, the $t_{1 / 2}$ of TNF$\alpha$-induced IL-6 message was $\sim 90 \mathrm{~min}$, and the inclusion of IL-6/sIL-6R did not affect the $t_{1 / 2}$ of the IL- 6 message. Therefore, the synergistic effect of TNF- $\alpha$ and IL-6/sIL-6R on IL-6 gene expression is likely caused by transcriptional regulation. Nuclear run-on analysis indicated that both TNF- $\alpha$ and IL-6/sIL-6R induce IL-6 transcription, which is enhanced in the presence of both stimuli (Fig. 6).

IL- $1 \beta$ alone is a more potent inducer of IL- 6 mRNA and protein than TNF- $\alpha$ (Fig. 4, Table 2). Our results provide the explanation for this: enhanced IL- $1 \beta$ induced IL-6 transcription and stabilization of the IL-6 message. Nuclear run-on analysis revealed that IL- $1 \beta$ induced IL- 6 gene transcription to a greater extent than TNF- $\alpha$ (6.7-fold for TNF- $\alpha$ vs 13.3-fold for IL-1 $\beta$ ) (Fig. 6). As well, IL- $1 \beta$ induces a more stable IL-6 message than TNF- $\alpha$ (Fig. $5 A, D$ ). Interestingly, IL- $1 \beta$ stimulation of cells for 1 hr induced an IL- 6 message with a $t_{1 / 2}$ of $\sim 60 \mathrm{~min}$, whereas a $6 \mathrm{hr}$ stimulation with IL- $1 \beta$ resulted in an IL- 6 message that did not undergo any appreciable decay for up to $18 \mathrm{hr}$ (Fig. $5 C, D$ ). Thus, it appears that there is a time dependence for IL- $1 \beta$-mediated stabilization of the IL- 6 message. In this regard, there are several reports of IL- $1 \beta$ stabilization of IL- 6 message. In murine mast cells, IL- $1 \beta$ alone has no effect on IL- 6 expression, but it enhances expression induced by c-kit ligand and IL-10 (Lu-Kuo et al., 1996). In fibroblasts, TNF- $\alpha$ and IL- $1 \beta$ synergistically stimulate IL- 6 expression that is caused in part by stabilization of the IL-6 message (Elias and Lentz, 1990). Interestingly, in those two studies, IL- $1 \beta$ alone did not stabilize the IL- 6 message, which is what we have observed in the U373-MG cells. Thus, the ability of IL- $1 \beta$ to stabilize the IL- 6 message may occur in cell type-specific manner.

IL- $1 \beta$ induction of IL- 6 protein expression was significantly enhanced in the presence of sIL-6R (Table 2), and elevated levels of IL- 6 mRNA were detected in cells treated with IL-1 $\beta$ plus IL-6/sIL-6R over treatment with either stimulus alone (Fig. $5 B$ ). The synergistic effect of IL- $1 \beta$ plus IL-6/sIL-6R appears to be caused by increased transcription of the IL- 6 gene in the presence of both stimuli (Fig. 6) because IL-6/sIL-6R does not affect the $t_{1 / 2}$ of IL- 6 message induced by IL- $1 \beta$ at either 1 or 6 hr (Fig. 5C,D). IL-6/sIL-6R has been shown to induce its own synthesis in osteoblasts by transcriptional mechanisms (Franchimont et al., 
1997), and our study also documents an effect of IL-6/sIL-6R on IL-6 transcription.

Co-treatment with TGF- $\beta$ plus the sIL-6R did not lead to synergistic increases in IL- 6 mRNA and protein expression (Fig. 4 , Table 2). The difference in the ability of TNF- $\alpha$ and IL- $1 \beta$, versus TGF- $\beta$, to synergize with IL-6/sIL-6R may be dependent on transcriptional regulation. TNF- $\alpha$ and IL- $1 \beta$ regulate IL- 6 transcription by similar mechanisms that involve use of NF- $\kappa \mathrm{B}$ and CCAAT enhancer binding protein $(\mathrm{C} / \mathrm{EBP})$ binding sites (Akira et al., 1990; Sparacio et al., 1992; Matsusaka et al., 1993; Miyazawa et al., 1998). Treatment of U373-MG cells with TNF- $\alpha$ and IL- $1 \beta$, but not TGF- $\beta$, leads to NF- $\kappa$ B interactions with the $\mathrm{NF}-\kappa \mathrm{B}$ response element in the IL- 6 promoter, as determined using electrophoretic mobility shift assays (data not shown). We hypothesize that synergy between TNF- $\alpha$ or IL-1 $\beta$ and IL-6/ sIL-6R requires NF- $\kappa$ B activation as well as the activation of an undetermined IL- 6 inducible transcription factor, possibly $\mathrm{C} / \mathrm{EBP} \beta$. $\mathrm{C} / \mathrm{EBP} \beta$ has been shown to function in the positive regulation of the IL- 6 promoter as well as other IL-6 inducible promoters (Miyazawa et al., 1998). Maximal IL-6 transcription as seen by TNF- $\alpha$ or IL- $1 \beta$ plus IL-6/sIL-6R may involve the interactions of NF- $\kappa \mathrm{B}$ and $\mathrm{C} / \mathrm{EBP} \beta$, as has been shown for IL-8 and serum amyloid A gene expression (Stein and Baldwin, 1993; Kunsch et al., 1994; Ray et al., 1995).

Most members of the IL-6 cytokine family act through ligandspecific receptors that interact with gp130 on binding ligand. OSM differs from this model in that OSM interacts first with gp130 (Gearing et al., 1992; Sporeno et al., 1994), then recruits either the LIFR $\beta$ (Thoma et al., 1994), a receptor used by various members of this family, or the OSMR, a receptor specific to OSM (Mosley et al., 1996). Other members of the IL-6 cytokine family were tested for effects on IL-6 expression; OSM induced IL-6 protein expression and strongly synergized with TNF- $\alpha$ for enhanced IL-6 expression. LIF alone induced a modest level of IL- 6 protein but did not synergize with TNF- $\alpha$ (Fig. 7). On the basis of the ability of OSM to significantly influence IL-6 expression, we propose that OSM along with IL-6 may affect the function of astrocytes. To our knowledge, no studies have been conducted to determine OSM expression in the brain. However, preliminary data indicate that human astrocytes, on stimulation, can produce OSM protein (our unpublished observation). This suggests a potential CNS source of this cytokine.

In summary, data presented herein support a positive autoregulatory role of IL-6 and the sIL-6R in astrocytes for IL-6 regulation. These findings may be relevant to inflammatory conditions in the brain, where cytokines such as TNF- $\alpha$ and IL-1 play an essential role in this process through the induction of chemokines and adhesion molecules, recruitment of immune cells into the CNS parenchyma, and ultimately, activation of immune cells and endogenous glial cells (for review, see Benveniste, 1997). In this context of elevated CNS expression of TNF- $\alpha$, IL-1 $\beta$, and IL- 6 , and the presence of the sIL-6R, a cytokine circuitry is established by which high levels of expression of IL-6 can occur, which may lead to some of the neuropathology associated with CNS inflammation. The ultimate biological effect of IL-6 in the CNS will depend on the availability of IL-6 receptors, both membrane bound and soluble forms, as well as the levels of soluble gp130, which can neutralize IL-6/sIL-6R complexes, thereby acting as an antagonist (for review, see Heinrich et al., 1998). Whether soluble gp130 exists in the CNS is not currently known; however, the expression of this component of the IL- 6 receptor signaling complex will impact on IL-6 biological effects in the CNS.

\section{REFERENCES}

Akira S, Isshiki H, Sugita T, Tanabe O, Kinoshita S, Nishio Y, Nakajima T, Hirano T, Kishimoto T (1990) A nuclear factor for IL-6 expression (NF-IL6) is a member of a C/EBP family. EMBO J 9:1897-1906.

Banning U, Bönig H, Pafferath B, Klein-Vehne A, Burdach S, Körholz D (1998) Release of the soluble interleukin-6 receptor from human t-cells. Immunol Invest 27:47-55.

Barnum SR, Jones JL, Benveniste EN (1992) Interferon-gamma regulation of C3 gene expression in human astroglioma cells. J Neuroimmunol 38:275-282.

Benveniste EN (1997) Cytokines: influence on glial cell gene expression and function. In: Neuroimmunoendocrinology (Blalock JE, ed), pp 31-75. Basel: Karger.

Benveniste EN (1998) Cytokine actions in the central nervous system. Cytokine Growth Factor Rev 9:259-275.

Benveniste EN, Sparacio SM, Norris JG, Grenett HE, Fuller GM (1990) Induction and regulation of interleukin- 6 gene expression in rat astrocytes. J Neuroimmunol 30:201-212.

Benveniste EN, Kwon JB, Chung WJ, Sampson J, Pandya K, Tang L-P (1994) Differential modulation of astrocyte cytokine gene expression by TGF- $\beta$. J Immunol 153:5210-5221.

Benveniste EN, Tang LP, Law RM (1995) Differential regulation of astrocyte TNF- $\alpha$ expression by the cytokines TGF- $\beta$, IL-6 and IL-10. Int J Dev Neurosci 13:341-349.

Bethea JR, Chung IY, Sparacio SM, Gillespie GY, Benveniste EN (1992) Interleukin- $\beta$ induction of tumor necrosis factor-alpha gene expression in human astroglioma cells. J Neuroimmunol 36:179-191.

Campbell IL, Abraham CR, Masliah E, Kemper P, Inglis JD, Oldstone MBA, Mucke L (1993) Neurologic disease induced in transgenic mice by cerebral overexpression of interleukin 6. Proc Natl Acad Sci USA 90:10061-10065.

Chung IY, Kwon J, Benveniste EN (1992) Role of protein kinase C activity in tumor necrosis factor- $\alpha$ gene expression: involvement at the transcriptional level. J Immunol 149:3894-3902.

Elias JA, Lentz V (1990) IL-1 and tumor necrosis factor synergistically stimulate fibroblast IL-6 production and stabilize IL-6 messenger RNA. J Immunol 145:161-166.

Eng LF, Ghirnikar RS, Lee YL (1996) Inflammation in EAE: role of chemokine/cytokine expression by resident and infiltrating cells. Neurochem Res 21:511-525.

Fischer M, Goldschmitt J, Peschel C, Brakenhoff JPG, Kallen KJ, Wollmer A, Grötzinger J, Rose-John S (1997) A bioactive designer cytokine for human hematopoietic progenitor cell expansion. Nature Biotech 15:142-145.

Franchimont N, Rydziel S, Canalis E (1997) Interleukin 6 is autoregulated by transcriptional mechanisms in cultures of rat osteoblastic cells. J Clin Invest 100:1797-1803.

Frieling JTM, Sauerwein RW, Wijdenes J, Hendriks T, van der Linden CJ (1994) Soluble interleukin 6 receptor in biological fluids from human origin. Cytokine 6:376-381.

Gadient RA, Otten UH (1997) Interleukin-6 (IL-6): a molecule with both beneficial and destructive potentials. Prog Neurobiol 52:379-390.

Gearing DP, Comeau MR, Friend DJ, Gimpel SD, Thut CJ, McGourty JM, Brasher KK, King JA, Gillis S, Mosley B, Ziegler SF, Cosman D (1992) The IL-6 signal transducer, gp130: an oncostatin M receptor and affinity converter for the LIF receptor. Science 255:1434-1437.

Gruol DL, Nelson TE (1997) Physiological and pathological roles of interleukin-6 in the central nervous system. Mol Neurobiol 15:307-339.

Hama T, Miyamoto M, Tsukui H, Nishio C, Hatanaka H (1989) Interleukin-6 as a neurotrophic factor for promoting the survival of cultured basal forebrain cholinergic neurons from postnatal rats. Neurosci Lett 104:340-344.

Heinrich PC, Behrmann I, Müller-Newen G, Schaper F, Graeve L (1998) Interleukin-6-type cytokine signalling through the gp130/Jak/STAT pathway. Biochem J 334:297-314.

Hirota H, Kiyama H, Kishimoto T, Taga T (1996) Accelerated nerve regeneration in mice by upregulated expression of interleukin (IL) 6 and IL-6 receptor after trauma. J Exp Med 183:2627-2634.

Jones SA, Horiuchi S, Novick D, Yamamoto N, Fuller GM (1998) Shedding of the soluble IL-6 receptor is triggered by $\mathrm{Ca}^{2+}$ mobilization, while basal release is predominantly the product of differential mRNA splicing in THP-1 cells. Eur J Immunol 28:3514-3522.

Klein MA, Möller JC, Jones LL, Bluethmann H, Kreutzberg GW, Raivich G (1997) Impaired neuroglial activation in interleukin-6 deficient mice. Glia 19:227-233. 
Kordula T, Rydel RE, Brigham EF, Horn F, Heinrich PC, Travis J (1998) Oncostatin $\mathrm{M}$ and the interleukin-6 and soluble interleukin-6 receptor complex regulate $\alpha_{1}$-antichymotrypsin expression in human cortical astrocytes. J Biol Chem 273:4112-4118.

Kunsch C, Lang RK, Rosen CA, Shannon MF (1994) Synergistic transcriptional activation of the IL-8 gene by NF- $\mathrm{B}$ p65 (RelA) and NF-IL-6. J Immunol 153:153-164.

Lee Y-J, Benveniste EN (1996) STAT-1 $\alpha$ expression is involved in IFN- $\gamma$ induction of the class II transactivator and class II MHC genes. J Immunol 157:1559-1568.

Lee Y-J, Han Y, Lu H-T, Nguyen V, Qin H, Howe PH, Hocevar BA, Boss JM, Ransohoff RM, Benveniste EN (1997) TGF- $\beta$ suppresses IFN- $\gamma$ induction of class II MHC gene expression by inhibiting class II transactivator messenger RNA expression. J Immunol 158:2065-2075.

Loddick SA, Turnbull AV, Rothwell NJ (1998) Cerebral interleukin-6 is neuroprotective during permanent focal cerebral ischemia in the rat. J Cereb Blood Flow Metab 18:176-179.

Lu-Kuo J, Austen K, Katz H (1996) Post-transcriptional stabilization by interleukin- $1 \beta$ of interleukin- 6 mRNA induced by $c$-kit ligand and interleukin-10 in mouse bone marrow-derived mast cells. J Biol Chem 271:22169-22174.

Lust JA, Donovan KA, Kline MP, Greipp PR, Kyle RA, Maihle NJ (1992) Isolation of an mRNA encoding a soluble form of the human interleukin-6 receptor. Cytokine 4:96-100.

März P, Cheng J-G, Gadient RA, Patterson PH, Stoyan T, Otten U, Rose-John S (1998a) Sympathetic neurons can produce and respond to interleukin 6. Proc Natl Acad Sci USA 95:3251-3256.

März P, Herget T, Lang E, Otten U, Rose-John S (1998b) Activation of gp130 by IL-6/soluble IL-6 receptor induces neuronal differentiation. Eur J Neurosci 10:2765-2773.

Matsusaka T, Fujikawa K, Nishio Y, Mukaida N, Matsushima K, Kishimoto T, Akira S (1993) Transcription factors NF-IL6 and NF- $\kappa$ B synergistically activate transcription of the inflammatory cytokines, interleukin 6 and interleukin 8. Proc Natl Acad Sci USA 90:10193-10197.

Miyazawa K, Mori A, Yamamoto K, Okudaira H (1998) Transcriptional roles of CCAAT/enhancer binding protein $-\beta$, nuclear factor- $\kappa \mathrm{B}$, and C-promoter binding factor 1 in interleukin (IL)- $1 \beta$-induced IL-6 synthesis by human rheumatoid fibroblast-like synoviocytes. J Biol Chem 273:7620-7627.

Mosley B, De Imus C, Friend D, Boiani N, Thoma B, Park LS, Cosman D (1996) Dual oncostatin M (OSM) receptors. Cloning and characterization of an alternative signaling subunit conferring OSM-specific receptor activation. J Biol Chem 271:32635-32643.

Müllberg J, Schooltink H, Stoyan T, Günther M, Graeve L, Buse G, Mackiewicz A, Heinrich PC, Rose-John S (1993) The soluble interleukin-6 receptor is generated by shedding. Eur J Immunol 23:473-480.

Nelson TE, Campbell IL, Gruol DL (1999) Altered physiology of purkinje neurons in cerebellar slices from transgenic mice with chronic central nervous system expression of interleukin-6. Neuroscience $89: 127-136$

Norris JG, Benveniste EN (1993) Interleukin-6 production by astrocytes: induction by the neurotransmitter norepinephrine. J Neuroimmunol 45:137-146.

Oh J-W, Van Wagoner N, Rose-John S, Benveniste EN (1998) Role of IL-6 and the soluble IL-6 receptor in inhibition of VCAM-1 gene expression. J Immunol 161:4992-4999.

Ray A, Hannink M, Ray BK (1995) Concerted participation of NF- $\kappa$ B and $\mathrm{C} / \mathrm{EBP}$ heteromer in lipopolysaccharide induction of serum amyloid A gene expression in liver. J Biol Chem 270:7365-7374.

Rose-John S, Heinrich PC (1994) Soluble receptors for cytokines and growth factors: generation and biological function. Biochem $\mathrm{J}$ 300:281-290.

Rosenman SJ, Shrikant P, Dubb L, Benveniste EN, Ransohoff RM (1995) Cytokine-induced expression of vascular cell adhesion molecule-1 (VCAM-1) by astrocytes and astrocytoma cell lines. J Immunol 154:1888-1899.

Satoh T, Nakamura S, Taga T, Matsuda T, Hirano T, Kishimoto T, Kaziro Y (1988) Induction of neuronal differentiation in PC12 cells by B-cell stimulatory factor 2/interleukin 6. Mol Cell Biol 8:3546-3549.

Shrikant P, Chung IY, Ballestas M, Benveniste EN (1994) Regulation of intercellular adhesion molecule-1 gene expression by tumor necrosis factor- $\alpha$, interleukin- $1 \beta$, and interferon- $\gamma$ in astrocytes. J Neuroimmunol 51:209-220.

Shrikant P, Weber E, Jilling T, Benveniste EN (1995) ICAM-1 gene expression by glial cells: differential mechanisms of inhibition by interleukin-10 and interleukin-6. J Immunol 155:1489-1501.

Sparacio SM, Zhang Y, Vilcek J, Benveniste EN (1992) Cytokine regulation of interleukin-6 gene expression in astrocytes involves activation of an NF- $\kappa$ B-like nuclear protein. J Neuroimmunol 39:231-242.

Sporeno E, Paonessa G, Salvati AL, Graziana R, Delmastro P, Ciliberto G, Toniatti C (1994) Oncostatin M binds directly to gp130 and behaves as interleukin-6 antagonist on a cell line expressing gp130 but lacking functional oncostatin receptors. J Biol Chem 269:10991-10995.

Stein B, Baldwin Jr AS (1993) Distinct mechanisms for regulation of the interleukin-8 gene involve synergism and cooperativity between C/EBP and NF- $\kappa$ B. Mol Cell Biol 13:7191-7198.

Taga T, Kishimoto T (1997) gp130 and the interleukin-6 family of cytokines. Annu Rev Immunol 15:797-819.

Thier M, März P, Otten U, Weis J, Rose-John S (1999) Interleukin-6 (IL-6) and its soluble receptor support survival of sensory neurons. J Neurosci Res 55:411-422.

Thoma B, Bird TA, Friend DJ, Gearing DP, Dower SK (1994) Oncostatin $\mathrm{M}$ and leukemia inhibitory factor trigger overlapping and different signals through partially shared receptor complexes. J Biol Chem 269:6215-6222.

Zhao B, Schwartz JP (1998) Involvement of cytokines in normal CNS development and neurological diseases: recent progress and perspectives. J Neurosci Res 52:7-16. 